\title{
Krešimir Purgar
}

\author{
Sveučilište u Zagrebu, Tekstilno-tehnološki fakultet, Prilaz baruna Filipovića 28a, HR-10000 Zagreb
} kpurgar@ttf.hr

\section{Modaliteti slikovnog pojavljivanja: temeljni pojmovi}

\begin{abstract}
Sažetak
Širenje digitalne tehnologije zahtijeva novo promišljanje slika: više im ne bismo smjeli pristupati samo kao starogrčkom eikonu, tj. odsliku ili reprezentaciji, nego i kao iskustvima, događajima i posebnoj vrsti pojava. U suvremenoj digitalnoj kulturi slikovno pojavljivanje je simptom najnovijega slikovnog obrata, tj. onoga koji se događa nakon pictorial turna, a koji su W. J. T. Mitchell i Gottfried Boehm prije gotovo tri desetljeća opisali kao epohalno novu vrstu odnosa slike i jezika. Danas svjedočimo drugačijoj vrsti urgencije: onoj koja će opisati odnos analognih slika i digitalnih slika, reprezentacije i postreprezentacije, realiteta $i$ virtualnosti, semiotike i fenomenologije. U ovome tekstu dat ću prijedlog jedne »tranzicijske« teorije slike koja uzima u obzir široki prostor između objekata i percepcije, tj. između eikona $i$ čiste osjetilnosti. U tu svrhu opisat ću četiri temeljna modaliteta slikovnog pojavljivanja: temporalnost, transparentnost, medijalnost i referencijalnost.
\end{abstract}

\section{Ključne riječi}

ontologija slike, slikovno pojavljivanje, Martin Seel, Dieter Mersch, temporalnost, transparentnost, medijalnost, referencijalnost

\section{Uvod: teorijski okvir pojavljivanja}

Premda se i dalje koriste kao označitelji u neprekinutom lancu semioze, slike danas sve manje »znače« i sve rjeđe reprezentiraju. Dostupnost digitalnog kodiranja dovela je do toga da je način njihova pojavljivanja, tj. ontološka razina slikovne spoznaje, informacijsko-komunikacijski važnija od ikonološko-semiotičke razine slikovne spoznaje. Na tragu ovoga tehnologijskog uvida proizlazi i potreba za novim promišljanjem odnosa estetike i aisthesisa. Njemački filozof Martin Seel objedinio je umjetnost, sliku i osjetilnost u novoj vrsti fenomenologijski utemeljenog tumačenja umjetničkih objekata koju naziva estetikom pojavljivanja [Ästhetik des Erscheinens]. ${ }^{1}$ Seelov koncept osmišljen je, prije svega, u svrhu estetske analize suštinski novih fenomena ljepote koji se u doba digitalnih komunikacijskih tehnologija realiziraju ne više kao označitelji klasične europske metafizičke tradicije, nego kao vizualne pojave što se estetski i umjetnički ostvaruju kroz navlastite mehanizme osjetilnosti. Najznačajniji doprinos njegove estetike pojavljivanja je upravo izostavljanje kriterija utemeljenih na povijesno-teorijskim kanonima ljepote, kao i relativiziranje povijesno-umjetničkih toposa: ovo ne znači da klasična

1

Martin Seel, Aesthetics of Appearing, Stan-

ford University Press, Stanford 2005. 
djela umjetnosti prestaju biti vrhuncima humanističke tradicije, nego znači da njihovo pojavljivanje, jednako kao i pojavljivanje bilo kojega drugog objekta, mora biti sagledano u svjetlu nove paradigme postajanja, nastajanja i događanja. Hoće li se objekt u svojem pojavljivanju konstituirati kao estetski objekt ili puka stvar, ovisi o promatračevim sposobnostima intuicije i imaginacije. Premda se Seel ne ograničava na slikovne medije, estetika pojavljivanja podrazumijeva postojanje modaliteta slikovnog pojavljivanja, ali ne i obratno. S obzirom da estetsko mora uključivati (i) slikovno, a slikovno ne mora uključivati estetsko, u ovom ćemo članku slikovnom pojavljivanju dati teorijsku samostalnost. Krenut ćemo od razlike što postoji između estetskog i bilo kojeg drugog objekta kako bismo otvorili raspravu o onome što definira aspekte »čiste« vidljivosti na jednoj strani i vidljivosti slike na drugoj.

Razlika između vizualnosti i slikovnosti usporediva je razlici između osjetilnosti i estetske percepcije. Seel to objašnjava ovako:

»U načelu, sve što se može osjetilno percipirati, može se i estetski percipirati. Među potencijalnim estetskim objektima ne nalaze se samo zamjetljive stvari i njihovi odnosi, nego događaji i njihov slijed - ukratko, sva stanja i pojave za koja možemo reći da smo ih vidjeli, čuli, dodirnuli, ili na neki drugi način osjetili. Usprkos tome, koncept estetskog objekta nije istovjetan konceptu nekog općenitog objekta percepcije jer ono što je estetski spoznatljivo može biti predmetom estetske percepcije, ali ne može samo zbog toga već unaprijed biti estetski objekt. Svi estetski objekti su objekti intuicije, ali nisu svi objekti intuicije estetski objekti.«²

Budući da ovakav stav jasno upućuje na Seelov polemički odnos prema nasljeđu metafizičke estetike, on se odmah na početku svoje analize jednako distancira i od tradicije analitičke filozofije umjetnosti nastale na tragu Arthura Dantoa: premda je suglasan s američkim filozofom da bilo koji objekt može posjedovati estetske kvalitete ( $\mathrm{tj}$. »da se može estetski percipirati«), Seel smatra da ta činjenica proizlazi iz načina pojavljivanja konkretnog objekta u vidljivom svijetu, a ne iz osobina koje smo tom objektu pripisali u nekom institucionalnom ili društvenom kontekstu. Seelova teorija je bitno fenomenološki određena jer je podjednako skeptična prema filozofsko-spekulativnom izvoru estetskog iskustva kao i prema njegovom konceptualnom poimanju. Utoliko on estetsko iskustvo vraća iz domene intelektualne spoznaje u domenu osjetilnosti, iz djelatnosti kritičke refleksije u događajnost i fenomenalnost pojavljivanja. ${ }^{3}$ Ovo je na izvjestan način povratak izvornome Kantovom učenju o »bezinteresnom sviđanju«: nije riječ o tome da estetski objekt ne smije imati nikakvu drugu svrhu nego kao predmet čistog estetskog uživanja, nego da je čovjekov um u stanju vidjeti ili doživjeti neki predmet - izvan ili s onu stranu njegove praktične funkcije - također $i$ kao estetski predmet. Duchamp nam nije ukazao na zanemarenu »ljepotu« pisoara niti je otkrio njegovu stoljećima zapretenu estetsku dimenziju, kao što Czanneovo slikarstvo nije zanimljivo zbog njegova (umjetnikovog) doživljaja prirode. Obojicu cijenimo, kao uostalom i većinu velikih umjetnika moderne, zbog promjene paradigme kreacije umjetničkog djela - od individualnog autorskog genija prema javnoj kritičkoj prosudbi, tj. od djela kao objekta prema promatraču kao subjektu.

Kako stoji stvar sa slikama općenito? Ima li (izvan-umjetničko) slikovno pojavljivanje i nekih drugih sličnosti sa znatno ekskluzivnijim Seelovim konceptom estetskog pojavljivanja, pored činjenice da nas u oba slučaja više zanimaju vizualno-osjetilni fenomeni od znakovno-tekstualne naracije? Zašto se slikovno iskustvo u vremenu i prostoru tehnosfere više ne može artikulirati kao ikonička razlika? Glavna teza ovog teksta je da je danas upravo percepcija razlike, tj. sposobnost razabiranja stvarnog od virtualnog iskustva slike mjesto odigravanja, baudrillardovski rečeno, »drame realnog«. Čini se da 
nam je u doba kada se tradicionalne slike sve manje razlikuju od imerzivnih sinestetičkih iskustava (koja jesu dijelom vizualni fenomeni, ali nisu samo slike), potrebna jednaka percepcijska usredotočenost da bismo prepoznali bilo izvoran umjetnički predmet bilo neki jednostavan slikovni objekt. ${ }^{4}$

Dieter Mersch, još jedan njemački autor bitan za našu raspravu, navodi da »logiku ikoničkih struktura« čini ista ona logika kojom percipiramo razlike između slike i okvira, tj. između slike i ne-slike, čime se ono ikoničko nadaje kao pojava i fenomen, prije negoli kao tekst ili znak. ${ }^{5}$ On tvrdi da je "slikovno vidljivo" drukčije vidljivo od »neslikovnog vizualnog« zato što slika posjeduje navlastit materijalni status pomoću kojega se ostvaruje razlika između, na jednoj strani, nečega što je vidljivo upravo kao slika i, na drugoj strani, nečega što je također vidljivo ali je puki vizualni fenomen koji nije slika. Mersch kaže da čak i gotovo potpuno imerzivno iskustvo IMAX kina još uvijek možemo smatrati slikom jer i dalje postoji granica koja uokviruje ono unutar-slikovno od okolnog vizualnog. ${ }^{6}$ Premda u ovom članku također tvrdim da je kod imerzije riječ o rubnom iskustvu slike, i premda se slažem s Merschom da je ovdje svakako još uvijek riječ o slikovnom fenomenu, ostaje pitanje je li to doista zbog toga što, kako on kaže, u kinu vidimo okvir platna i stolice ispred sebe te osjećamo specifičan kino-aranžman, ili je to ipak zato što znamo da je riječ o kinematografskom aparatu i tradicionalnoj instituciji kina koja svoj iluzionistički karakter nije mijenjala od početka ere pokretnih slika? Doduše, mnogo važniji od ove epistemološke spekulacije za nas će biti Merschov fenomenološki uvid prema kojemu su upravo imerzivna iskustva slike ona koja potiru temelje slikovne ontologije:

»Sav tehnički iluzionizam, ono što se može nazvati 'slikovnom imerzivnošću', u tome pronalazi svoju dinamiku i svoju uzaludnost. « ${ }^{7}$

Naime, to što slika pokušava jednako je paradoksu:

»... brisanje onog što je konstitutivno za viđenje slike, a time i brisanje same slikovnosti kao medija. Logika tehničkog proizlazi iz tog telosa: medija koji negira vlastitu medijalnost. $\aleph^{8}$

Iz ovoga slijedi da je uočavanje modaliteta slikovnog pojavljivanja temeljni preduvjet kako mogućnosti estetske percepcije tako i percepcije slika općenito kao fenomenâ koji posjeduju drugačiju unutrašnju logiku od realiteta (ili kontinuuma stvarnosti) u kojemu se kao objekti percepcije nalaze. Te modalitete je potrebno precizno definirati iz dva temeljna razloga: prvo, zato što oni mogu baciti novo svjetlo na još nerazriješene aporije slikovnog obrata, prvenstveno onoga njegovog dijela što se bavio pitanjem dominacije tekstualnog nad vizualnim i obratno; i drugo, zato što tehnosfera postavlja potpuno nove izazove pred slikovnu medijalnost: naime, postavlja se pitanje na koji

Ibid., str. 21-22.

Ibid., str. 23.

Vidi Krešimir Purgar, »Što (više) nije slika: ikonička razlika, imerzija i ikonička simultanost u doba kulture ekrana«, Filozofska istraživanja 137 (1/2015), str. 153-169.

5

Dieter Mersch, »Pogled i izmicanje: uz logiku ikoničkih struktura«, Tvrđa (1-2/2012), str. 140-150. Originalno izdanje: »Blick und
Entzug. Zur Logik ikonischen strukturen«, $\mathrm{u}$ : Gottfried Boehm, Gabriele Brandstetter, Achatz von Müller (ur.), Figur und Figuration, Wilhelm Fink, München 2007.

6

D. Mersch, »Pogled i izmicanje: uz logiku ikoničkih struktura«, str. 141.

7

Ibid., str. 142.

8

Ibid. 
način sačuvati čovjekovu sposobnost umjetničkog transcendiranja stvarnosti kada iskustva slikovne reprezentacije - tradicionalno slikarstvo i kinematografija $\mathrm{u}$ »staromodnoj « 2D tehnici, primjerice - nestaju u digitalnim svjetovima virtualnosti, a u kojima pak transcendencija više nije moguća? Ako je umjetnost u pred-digitalnom vremenu bila jedino sredstvo pomoću kojeg je bilo moguće prekoračiti granice spoznaje i sagledati realitet izvan okvira puke nužnosti, tada virtualni prostor nekog imerzivnog realiteta čini umjetnost danas podjednako nemogućom i nepotrebnom. Kao što nam to sugeriraju Martin Seel i Dieter Mersch, nova strategija umjetnosti utoliko mora biti identična novoj strategiji slike: naime, ono ikoničko što je u tekstu iz 1978. Gottfried Boehm još mogao nazvati slika-kao-razlika, u epohalnom obratu tehnoznanstvenog doba treba se pretvoriti u sliku-kao-pojavljivanje.

Da bismo uspostavili plauzibilni model općega slikovnog pojavljivanja uzimajući u obzir podjednako promjene u medijalnosti slika, kao i Merschovu opreku slikovno/vizualno (a što je jedan od temeljnih prijepora digitalnog doba), nužno je slike osloboditi »viška« upisanog sadržaja, tj. pristupiti im kao apstraktnim entitetima: pritom ne mislim nužno na slike apstraktne umjetnosti, nego na slike kao objekte oslobođene kulturološki naslijeđenog estetskog sadržaja. ${ }^{9}$ Martin Seel u Estetici pojavljivanja zadaje si teži zadatak jer ne samo da nastoji odvojiti »faktualnu« vrstu pojavljivanja (konstitutivnu za bilo koji objekt) od konkretnog »fenomenalnog« pojavljivanja (a što je preduvjet estetskog razlikovanja), nego nastoji i unutar željene estetske norme uspostaviti kriterije uočavanja onih fenomena koji sudjeluju samo u estetici pojavljivanja. Za razliku od pristupa estetskom objektu u tradicionalnim hermeneutičkim disciplinama, poput povijesti umjetnosti primjerice, kod kojih se nekom predmetu - slici ili trodimenzionalnom objektu - pripisuju umjetničke osobine u procesu interpretacije, Seelova metoda pretpostavlja proces oduzimanja ili apstrahiranja mnoštva pojavnih fenomena nekog predmeta i skretanje pozornosti na samo one fenomene koji su estetski relevantni. Taj proces estetskog reduciranja svih onih zapravo neograničenih i nikad do kraja sagledivih fenomena koji sačinjavaju univerzalnu činjeničnost nekog predmeta on naziva »simultanim i trenutnim pojavljivanjem pojavnostî« (»simultaneous and momentary appearing of appearances «). ${ }^{10}$ Drugim riječima, nešto se može pojaviti ili pojavljivati na specifičan način, u nekom kontekstu i pri specifičnom načinu gledanja, bez obzira na sve one univerzalne i trajne osobine tog predmeta po kojima ovaj inače ne bi bio osobito estetski zanimljiv. Pojavnost (appearance) predmeta je njegova univerzalna faktualnost po kojoj predmet prepoznajemo unutar jedne klase vizualno i haptički spoznatljivih objekata. S druge strane, pojavljivanje (appearing) je estetska operacija vizualnog fokusiranja i osjetilnog sagledavanja objekta u novome statusu: istodobno oslobođenome mnogostrukosti svojih svakodnevnih pojavnosti kao i obogaćenome jedinstvenim »simultanim i trenutnim《 pojavljivanjem.

Kod ovog njemačkog autora riječ je, kako vidimo, prije svega o modelu razumijevanja umjetničkih objekata, dok se naša analiza odnosi prvenstveno na mnogo općenitiji pojam slikovne diferencije. Utoliko modaliteti slikovnog pojavljivanja koje ću ovdje predložiti nisu sasvim usporedivi s pojavljivanjem kao estetskom kategorijom opisanom kod Martina Seela, ali nisu niti općenite kategorije pojavnosti - onoga puko vizualnog ili vidljivog. Koristit ću Erscheinen tek djelomično u Seelovom smislu, prvenstveno tu mislim na apstrahiranje simboličko-narativnog sadržaja slike kroz svojevrsni fenomenološki obrat od tekstualne prema ikoničkoj supstanci umjetničkog (u našem slučaju slikovnog) objekta. Pokušat ću, dakle, približiti fenomenološke modele koji se pozivaju na Seelov događaj i trenutak pojavljivanja, zatim Boehmovu iko- 
ničku razliku kao i Merschovo slikovno vidljivo, te ih primijeniti uzimajući u obzir prije svega konzekvence Paićevog tumačenja tehnosfere, a koje tumačenje dramatično skreće pozornost na sasvim novo značenje pojmova poput stvarnog, simuliranog i virtualnog. ${ }^{11}$ Namjera mi je u nastavku opisati četiri temeljna modaliteta slikovnog pojavljivanja kao osnove za jednu novu teoriju slike digitalnog doba izvan esencijalističko-subjektivističkih aporija. Ti modaliteti su: temporalnost, transparentnost, medijalnost i referencijalnost.

\section{Temporalnost: reprezentacijske, simultane i recipročne slike}

Najvažnija promjena koju je digitalna tehnologija donijela u sveukupnu vizualnu kulturu jest potpuno novi učinak vremena u proizvodnji i percepciji slike. Naime, osnovna karakteristika reprezentacije, tj. reproducirane slike - bez obzira je li riječ o slici na platnu, fotografiji ili filmu - jest to da je uvijek riječ o vizualnom fenomenu koji je nastao nakon reprezentiranog događaja. Smisao reprezentacije i vizualnih umjetnosti koje su se na njoj temeljile tijekom višemilenijske povijesti slika bio je upravo u omogućavanju odvajanja iskustva života kao temporalnog kontinuuma od iskustva umjetnosti kao reza unutar kontinuuma. Sve do pojave izravnih televizijskih prijenosa pomoću video-linkova ili nešto kasnije pomoću satelita, svaka slika je mogla biti samo reprezentacija, dakle slika je uvijek slijedila načelo temporalne drugosti ili diskontinuiteta u odnosu na nezaustavljivi tijek vremena. Slika je zaustavljala vrijeme, premda to nije bila njena glavna ontološka osobina jer se problem slikovnog anakronizma uvijek već unaprijed doživljavao kao prirođen onome što slika jest - tj. zaustavljenom vremenu koje se uvijek već dogodilo. Budući da niti jedna slika nastala prije dvadesetog stoljeća nije mogla biti istodobna događaju koji prikazuje, problematika temporalnosti sagledavana je u odnosu na karakteristike unutarslikovnog prikaza, a ne u odnosu na ishodišni realitet. Bez obzira o koliko dugom trajanju vremena reprezentiranog na slici bila riječ, svaka je reprezentacija ontološki podudarna bilo kojoj drugoj.

Uzmimo kao primjer prikaz pokreta na četiri potpuno odvojene kategorije reprezentacije koje sve prikazuju neku vrstu ili stadij kretanja, ali se razlikuju po medijskoj osnovi: Caravaggiovo Polaganje Krista u grob iz 1603.; seriju

9

U drugom dijelu Seelove knjige Estetika pojavljivanja nalazi se esej pod naslovom »Trinaest teza o slici« u kojemu njemački autor izričito tvrdi da se problematika ontologije slike jasnije otvara ako pođemo od apstraktnih slika zato što one ne nose »teret« reprezentacije: »Svaka teorija slike mora s jedne strane objasniti kako je slikovni objekt povezan sa slikovnim prikazom, a s druge strane kako je slikovni prikaz povezan s reprezentacijom.« Drugim riječima, pojam reprezentcije u svakom slučaju komplicira što jest sama slika jer je evidentno da je reprezentacija prije svega odnos između prisutnosti prikazanog na slici i njegova neprisutnog referenta. Upravo zato će, kada je riječ o nefigurativnim slikama, Seel konstatirati da se takozvana apstraktna slika »dokazuje kao najkonkretnija i stoga paradigmatska slika«. Vidi M. Seel, Aesthetics of Appearing, str. 161-163.
10

Ibid., str. 46.

11

Žarko Paić je među hrvatskim autorima najsustavnije govorio o pojmu tehnosfere kao terminu koji označava posljedice tehnologijskoga obrata u humanističkome razumijevanju svijeta. Za njega je tehnosfera nov prostor i vrijeme slike u kojemu digitalna konstrukcija stvarnosti nema cilj stvoriti novu utopiju ili nov model prikazivanja svijeta, nego ona sama sada jest taj novi svijet. Vidi o tome u: Žarko Paić, Treća zemlja. Tehnosfera i umjetnost, Litteris, Zagreb 2015. O kontekstualizaciji pojma tehnosfere unutar znanosti o slici, te o generalnom Paićevom problematiziranju tog koncepta vidi Krešimir Purgar, »Nulti stupanj reprezentacije. Umjetnost, tehnika i slikovno pojavljivanje«, Ars Adriatica 6 (2016), str. 241-252. 
fotografija konja u galopu Eadwearda Muybridgea iz 1878., te njegov protokinematografski uređaj nazvan zoopraxiscope; zatim sliku Marcela Duchampa Akt silazi niz stepenice iz 1912., skulpturu Umberta Boccionija Kontinuitet prostora iz 1913. i naposljetku ulje na platnu Gerharda Richtera Žena silazi niz stepenice iz 1965. Da bi prikazao pokret, svaki od spomenutih autora morao je pronaći način kako kondenzirati vrijeme potrebno da bi se pokret uopće razlikovao od prikaza neke statične scene. Fotografija, ulje na platnu i skulptura zahtijevaju intervenciju u sadržajni i stilski sklop kako bi prikaz bio protumačen temporalno, dok je filmu dovoljna samo medijska osnova: čak i izrazito statičan filmski prikaz uvijek će »odavati« prisutnost vremena putem jedva zamjetljivih pomaka. ${ }^{12}$ Statična reprezentirana slika ne posjeduje neko samo sebi svojstveno vrijeme nego je ovisna o temporalnosti koju prikazuje; klasični tableau mogao je uhvatiti samo onaj trenutak koji doista vidimo na slici. Budući da na Caravaggiovom Polaganju Krista u grob ne vidimo ono što je prikazanom trenutku neposredno prethodilo, kao niti ono što mu neposredno slijedi, kondenzacija vremena ostvarena je dramatičnom gestualnošću likova koja je u stanju tek nagovijestiti kontinuitet čina polaganja u grob.

Kod Boccionija i Richtera temporalnost je prikazana s istim ontološkim ograničenjem medija (jedan slikovni kadar i jedan skulpturalni volumen), ali je stilskom inovacijom obaju autora mnogo izravnije sugerirano da je ono nevidljivo vrijeme (tj. na slici izostavljeno, neprikazano vrijeme) prije i poslije reprezentiranog trenutka ipak postojalo. Richter je to vrijeme pokazao oponašajući dugu ekspoziciju fotografskog aparata, dok je Boccioni isti učinak postigao spajanjem zamišljenog niza vremenskih sekvenci u jedan jedinstveni volumen. Dakle, obojica su, uključujući Caravaggia i Duchampa, morala žrtvovati realističnost prikaza kako bi unutar statičnih medija prikazali vrijeme. Na drugoj strani, Muybridge nam je pomoću eksperimenta s konjem u galopu pokazao da novi medij pokretnih slika neće poznavati to ograničenje: film, naime, prikazuje vrijeme samom svojom medijskom prirodom, on ne postoji bez vremena potrebnog za brzu izmjenu mnoštva statičnih slika/frameova.

Film Andyja Warhola Empire iz 1964. na drastičan način pokazuje kako bi izgledala kinematografska reprezentacija bez specifično filmske montažne kondenzacije filmskog vremena: kao jedinstveni kontinuirani kadar koji teoretski može trajati onoliko dugo koliko »traje« jedan kolut filmske vrpce. Prema tome, kinematografsko vrijeme približilo se ili čak potpuno poistovijetilo sa stvarnim vremenom ali - što je za ovu raspravu naročito važno - nikada nije prestalo biti reprezentacija. Naime, ono što se u Warholovom filmu događa, premda je gotovo identično stvarnoj slikovno-temporalnoj situaciji ispred kamere, nužno prikazuje vrijeme koje je nepovratno prošlo. Na samom filmu, doduše, ipak se vide trenuci montažnog reza kada Warhol i njegov snimatelj Jonas Mekas mijenjaju filmske vrpce. Rezultat ove manipulacije stvarnim i filmskim vremenom je taj da je temporalni kontinuitet i potpuno poistovjećenje dvaju realiteta narušeno samo zbog tehnoloških ograničenja filmskog medija. ${ }^{13} \mathrm{Ili}$, drugačije rečeno, upravo je tehnološko ograničenje medija skrenulo pozornost na njegov temeljno manipulativni, a time i potencijalno umjetnički karakter.

Najvažnije pitanje tek slijedi: što se događa sa slikovnom reprezentacijom kada tehnološka ograničenja klasičnog analognog filmskog ili slikarskog medija ustupe mjesto ikoničkoj simultanosti digitalnog doba? U odgovoru na ovo pitanje krije se i razlog zašto je ukazivanje na problematiku temporalnosti - a ne reprezentacije - prvi zadatak teorije slike danas. Moja teza glasi ovako: prije pojave izravnih televizijskih prijenosa i prije satelitske pokrivenosti 
čitavog planeta reprezentaciju smo s pravom mogli smatrati kao ontološku specifičnost svakog slikovnog prikaza. Usprkos njegove trajne validnosti kao filozofskog i fenomenološkog pojma, Gottfried Boehm svojem konceptu ikoničke razlike nije smatrao potrebnim priložiti i neku vrstu tehno-znanstvene legitimacije, a koja legitimacija bi danas ipak mnogo sudbonosnije odredila razliku između slike i ne-slike, nego što nam on to predlaže u svom ključnom tekstu »Povratak slika« iz 1994. Naime, zaokret prema slici - ikonički obrat - Boehm tada prepoznaje u obratu prema slici poglavito u Wittgensteinovoj filozofiji jezika i Merleau-Pontyjevoj fenomenologiji duha, a ne u zaokretu od tradicionalne reprezentacije prema drugačijim i novijim tehnologijama vizualizacije. Isti problem primjećujemo i kod Mitchellovog slikovnog obrata iz iste godine $\mathrm{u}$ kojemu je zaokret prema slici protumačen iz pozicije ideološke kritike postojećih vizualnih režima, a ne iz duha tehnike koji nepovratno i radikalno mijenja metode slikovne spoznaje; to nam ujedno objašnjava zašto Craryjevu knjigu Techniques of the Observer Mitchell tada tumači prije svega kao zbirku tehnoloških simptoma moderne vizualne kulture. ${ }^{14}$ Premda Mitchell u svome čuvenom tekstu ne prepoznaje tehniku kao glavnog pokretača zaokreta prema slici i ne misli da ona može radikalno odvojiti promatrača od njegove »ljudske prirode«, on ipak priznaje Craryju da suvremene tehnike vizualizacije, poput CAD sustava, sintetičke holografije, simulatora letenja, kompjutorske animacije, kontrole pokreta ili multispektralnih senzora, mogu pridonijeti moralnom i političkom strahu od »gubitka ljudskog «. ${ }^{15}$

$\mathrm{Na}$ ovome mjestu ne bismo išli tako daleko i govorili o gubitku ljudskog, ali o novoj ontologiji slike mislim da je opravdano govoriti. Naime, ako vizualne pojave sagledavamo u okviru koncepta tehnosfere, dakle iz pozicije tehnoloških mogućnosti vizualizacije, onda ćemo primijetiti da je klasična reprezentacija danas samo jedan od tri ravnopravna oblika prikazivanja: druga dva su simultane i recipročne slike, a sve tri kategorije čine novu, temporalnu dimenziju slike. Zašto je nužno govoriti o vremenskoj dimenziji i na koji način vrijeme utječe na prirodu slikovnog iskustva? Bitno je razumjeti da ovdje nije riječ o onoj vrsti vremena koje je potrebno da specifični vremenski mediji, poput digitalnog ili analognog filma, ili još ranijeg zoopraxiscopea i

12

Uvodna scena Hanekeovog filma Skriveno dobar je primjer »izdajničkog« i manipulativnog karaktera filmskog vremena. Izrazito statičan prvi kadar u Hanekeovom filmu ima dvostruku ulogu: strukturalnu i narativnu. $\mathrm{Na}$ strukturalnoj, razini statičan kadar snimljen fiksnom kamerom najavljuje režiserovu manipulaciju filmskom temporalnošću kao temeljnom konstruktivnom odrednicom filma. Na sadržajnoj razini, statičan kadar koji se produžuje $\mathrm{u}$ vrijeme najavljuje tematsku okosnicu filma, tj. psihološki učinak promatranja i bivanja promatranim (Michael Haneke, Skriveno, 2005., gl. uloge Daniel Auteuil i Juliette Binoche).

13

Mislim da moj argument nije nimalo doveden u pitanje činjenicom da je Warholov Empire prikazan usporeno u odnosu na brzinu kamere korištenu tijekom snimanja. Snimatelj Jonas Mekas snimao je ikonički njujorški neboder klasičnom filmskom brzinom od 24 sličice/ framea u sekundi, a Warhol je film odlučio prikazivati s brzinom od 16 sličica u sekundi Intervencije su uključivale i minimalnu montažu (premda je ovdje prije riječ o montaži »iz nužde«) jer nije bilo tako velikog koluta filmske vrpce na koji bi mogao biti snimljen vizualni materijal u neprekidnom trajanju od šest i pol sati koliko je ukupno trajanje snimljenog materijala. Moj argument temelji se prije svega na Warholovoj ideji da pokaže stvarno fizičko vrijeme kao potpuno nesukladno manipulativnom karakteru filma kao umjetničke forme. Ta ideja, naime, mogla je biti prenesena i neprekinutim trajanjem filma od dva sata, koliko to dopušta samo jedan kolut filmske vrpce.

14

Vidi o tome više u William J. T. Mitchell, Picture Theory, Chicago University Press, Chicago 1994., str. 23-25.

15

Ibid. 
kinetoskopa, proizvedu pokret, nego o stvarnom vremenu koje se upravo sada odvija $u$ slici. Kada gledamo bilo koju filmsku reprezentaciju, bez obzira je li riječ o montiranim sekvencama karakterističnima za narativni film ili o kontinuiranom, ekstremno dugom kadru svojstvenom za eksperimentalne filmove (poput Warholovog filma Empire), riječ je o točno određenom vremenu koje se uvijek već dogodilo. Sama ideja filmskog fictiona, pa i dokumentarnog factiona, računa sa slikama vremena koje je prošlo. S druge strane, danas je sve više slučajeva medijske eksploatacije slikovnog vremena koje se upravo događa, koje je istodobno onome tko gleda, onome što se gleda i onome putem čega se gleda. Promatrač, promatrano i medij promatranja dijele identičan vremenski kontinuum. Ovaj oblik vizualizacije nije nov i pomalo je paradoksalno da je u osvit televizijskog doba, u dvadesetim godinama prošlog stoljeća, upravo izravni prijenos bilo lakše ostvariti nego snimiti emisiju na nekom mediju za pohranu podataka. ${ }^{16}$ Live slike formiraju se kao vizualne činjenice upravo u trenutku u kojemu bivaju emitirane i bez upravo tog trenutka same ne mogu postojati.

Takve simultane slike poprimaju sasvim drugačiji karakter u našem vremenu kada ih više ne koristi samo industrija zabave i servisi javnog informiranja kako bi nas uključili u neki sportski događaj ili nam prenijeli dramu prirodnih nepogoda, nego je ikonička simultanost iskorištena kako bi zamijenila nešto mnogo materijalnije: fizičku prisutnost. Korištenje dronova u raketnim napadima iz zraka, mogućnost nadgledanja u realnom vremenu svakog komadića naše planete, nadzorne kamere u javnim prostorima - sve to su primjeri simultanih slika. Te slike ne reprezentiraju, one prezentiraju; one su inkarnacija vremena i prisutnosti događaja, ono tamo i ono ovdje zajedno su uprisutnjeni u kontinuumu vremena i, za razliku od reprezentacija, bez kontinuuma ne postoje. Podvrsta simultanih slika su recipročne slike koje također posjeduju sve osobine istodobnosti, uz značajnu razliku da je učinak prisutnosti omogućen i promatraču i promatranome. Dostupnost digitalnih servisa, poput Skypea, i obećanje virtualne tehnologije, zamislivo već danas pomoću imerzivnih vizualizacija Oculus Rifta i Samsung VR-a, dovest će do toga da će recipročne slike u bliskoj budućnosti pružiti potpuno imerzivno iskustvo. U tradicionalnoj klasifikaciji, u kojoj su slike uvijek bile reprezentacije, ovakva vizualna iskustva više ne bi mogla biti smatrana slikama; u novoj klasifikaciji koju ovdje predlažem one su novi, specifični prostorno-događajni fenomeni u sferi vidljivog. ${ }^{17}$

Kriterij temporalnosti izravna je posljedica novih tehnologija prikazivanja i prijenosa vizualnih informacija i ne ovisi o tehnikama reprezentacije ili reprodukcije te ga ne možemo dovesti u vezu s individualnim vještinama proizvodnje slika u najširem smislu (slikarske, crtačke, snimateljske tehnike i sl.). I sada dolazimo do paradoksa: premda je informacijska tehnologija omogućila nesagledive mogućnosti stvaranja i komunikacije pomoću simultanih i recipročnih slika, reprezentacijske slike su još uvijek glavni medij umjetnosti, dok novu tehnologiju vizualnog simultanizma koristimo uglavnom u proizvodnji ne-fikcionalnih sadržaja. Znači li to da vrijeme koje je »uvijek već prošlo« i dalje omogućava kreativniju manipulaciju fikcijskim (umjetničkim) sadržajima ili to znači da umjetnička imaginacija ne može uhvatiti korak s najnovijim tehnikama simultane i recipročne vizualizacije; ili je, možda, ipak riječ o tome da slikovni simultanizam još uvijek doživljavamo jednostavno kao stvarnost, a ne kao umjetnost? Čini se da magičan učinak umjetničke kontingencije slike nimalo ne blijedi niti pred sveprisutnim simultanizmom live-streaminga niti pred imanencijom postreprezentacije koja je simultanizmu svojstvena. 


\section{Transparentnost: netransparentne, transparentne i imerzivne slike}

Podjela prema transparentnosti govori o semiotičkom i fenomenološkom učin$k u$ slikovne površine: drugim riječima, ona govori o tome koju vrstu vizualne informacije prepoznajemo na komadu papira, slikarskom platnu, filmskom ili televizijskom ekranu. Kao što ćemo malo kasnije vidjeti, transparentnost je u neposrednoj vezi s referencijalnošću, ali je kod transparentnosti presudno kako vidimo, dok je kod referencijalnosti mnogo važnije što vidimo. U načelu možemo reći da je u tradicionalnom konceptu reprezentacije »razumljivost« slike veća što je izraženija njena prozirnost. Ovaj aksiom proizlazi iz koncepta renesansne slike kao prozora u svijet i iz toga što je zapadna kultura preuzela ovo reprezentacijsko načelo kao prirodan oblik prenošenja trodimenzionalne stvarnosti u različite medije dvodimenzionalnih reprezentacija. Budući da je cjelokupna klasična tradicija utemeljena na prirodi kao uzoru ljepote i na Aristotelovom načelu oponašanja prirode kao cilja pjesničkog umijeća, ono što je na slici transparentno, tj. ono što kroz nju vidimo, upravo je prirodni svijet i čovjekove intervencije u prirodnom svijetu (arhitektura, odjeća, tehnička pomagala, itd.). Što više elemenata iz prirode smo u stanju »prepoznati« na nekoj slici, to ćemo za tu sliku reći da je realnija i realističnija; ona time postaje transparentnija jer »kroz nju « prepoznajemo ono što slika prikazuje.

Prvi paradoks načela transparentnosti, koji doduše nimalo ne umanjuje vjerodostojnost tog načela, sadržan je u tome što realističnost slike nužno vodi prema dominaciji slikovnog sadržaja nad slikovnim fenomenom. Drugim riječima, što je pozornost promatrača više usmjerena prema onome što slika reprezentira, svijest o samome fenomenu reprezentacije bit će manja. Uzmimo, na primjer, digitalni medij pokretnih slika koji može biti i maksimalno proziran i vrlo neproziran: izrazito realističan prikaz terorističkog napada snimljen pametnim telefonom visoke rezolucije od strane sudionika s mjesta događaja, doživjet ćemo poput visokotehnološkog snapshota, gotovo kao suvremenu verziju talijanskog baroknog tableaua - ali, što je naročito važno - nećemo u njemu prepoznati umjetničke pretenzije. Ukoliko je pak snimka mutna, pretamna ili je nedovoljne rezolucije jer je snimljena izdaleka pomoću nadzorne kamere, promatračeva pozornost bit će više usmjerena na formalne ili tehničke nedostatke slike i zato će on više biti fokusiran na njena fenomenologijska svojstva. Pitanja koja će si promatrač pritom postavljati više će zadirati u područje slikovnog iskustva (»jesam li siguran u ono što vidim«), negoli u domenu slikovnog sadržaja (»je li se doista sve baš tako dogodilo«). Netransparentnost i djelomična prozirnost upućuju na sâm medij zato što se u uvjetima smanjene realističnosti prikaza između promatrača i svijeta ispriječio onaj metaforički prozor koji je u slučaju nejasne snimke zamagljen, a kod slika apstraktne umjetnosti i potpuno neproziran. Na tragu Martina Seela i njegovih »Trinaest tvrdnji o slici« možemo potvrditi da se paradoks, dakle, sastoji u tome što je slikovno iskustvo utoliko izraženije ukoliko je transparentnost manja ili, još jednostavnije kazano, više ćemo biti svjesni same slike i njene medijske osnove ako si ne postavljamo pitanje što slika prikazuje.

16

O tome više vidi u tekstu Stefana Münkera »Eyes in the Window: Intermedial Reconfiguration of TV in the Context of Digital Public Spheres«, u: Žarko Paić, Krešimir Purgar (ur.), Theorizing Images, Cambridge Scholars Publishing, Newcastle 2016.
17

O vizualnom iskustvu koje se više ne može smatrati slikom pišem opširnije u ranije spomenutom tekstu »Što (više) nije slika«. 
Drugi paradoks načela transparentnosti, za koji ću nastojati pokazati da možda još više od prethodnog potvrđuje teorijsku relevantnost problema slikovne prozirnosti, sastoji se u tome što eventualno dosezanje ideala potpune transparentnosti i potpune imerzivnosti eliminira samu mogućnost slikovnog iskustva. Budući da, kako smo malo prije spomenuli, transparentnost možemo smatrati čovjekovim naturaliziranim sustavom prepoznavanja sadržaja slike, proizlazi da će transparentnost biti prisutna u onoj mjeri u kojoj »prirodnim« putem uspijemo prepoznati realističnost slikovnog sadržaja ili, kako bi Kendall Walton rekao, u onoj mjeri u kojoj u slici uspijemo »vidjeti svijet«. Ovaj autor smatra da između izrazito transparentnih slika, poput fotografija, i onih tek nešto malo manje transparentnih, poput hiper-realističnih slika na platnu, ipak postoji suštinska razlika. Prema Waltonu, fotografije posjeduju "malo više« od onih osobina prozirnosti koje drugim vrstama slika nedostaju: međutim, razlike u stupnju transparentnosti nisu dovoljne, smatra on, da bismo između različitih vrsta slika uspostavili esencijalni rez. ${ }^{18}$ Ovaj američki filozof analitičke orijentacije pritom se poziva na fenomenološke uvide o prirodi slikovnog iskustva, tj. na pojmove poput razlike i reza za koje unutar teorije slike možemo reći da su podjednako popularne i u novijim teorijama europske tradicije, prvenstveno tu mislim na slikovno-teorijski opus Gottfrieda Boehma i Jean-Luca Nancyja.

Kendall Walton smatra da transparentnost fotografije sama po sebi ne pridonosi njenoj realističnosti jer je fotografija u fenomenološkom smislu uvijek odvojena od kontinuuma površine na kojoj se nalazi i već je ta odvojenost dovoljna da svaka slikovna površina posjeduje ontološku drugost, bez obzira na stupanj transparentnosti: plošnost fotografije, njen okvir, zid na kojemu je obješena, sve su to elementi koji pridonose njenoj očevidnosti - »fotografije izgledaju upravo kao ono što same jesu: fotografije «. ${ }^{19}$ Ova tvrdnja, dakako, ne ide $u$ prilog mojem argumentu, $t \mathrm{j}$. spomenutom drugom paradoksu načela transparentnosti, međutim Walton pripisuje transparentnosti fotografije neke osobine koje se nikako ne mogu pripisati drugim vrstama vizualnih reprezentacija. Naime, u svom ranijem i najpoznatijem djelu Mimesis as Make-Believe Walton tvrdi da je realističnost mimetičke reprezentacije proizvedena nizom konvencija, od kojih je primarna konvencija to da se određeni prikazi u nekim situacijama smatraju istinitima, bez obzira što su sami po sebi fikcionalni. ${ }^{20}$ Iz toga proizlazi da prepoznavanje stvarnosti na slici nije racionalno utemeljeno, nego je proizvod »igre mašte« koja se uvijek odvija prema unaprijed zadanim pravilima. Prema toj teoriji, transparentnost ili mimetičnost realističkih slika iz povijesti umjetnosti nije plod traganja za savršenom reprezentacijom stvarnosti nego je riječ o nizu povijesno promjenjivih pravila »igara mašte« (make-believe). Premda je, primjerice, svaki realistički načinjeni portret uvijek i samo fikcijska zamjena za stvarnu prisutnost naslikane osobe, u fikcijskom svijetu mimetičke igre mašte ta je osoba doista na slici prisutna. Walton o tome kaže:

»Fikcionalnost je u nekim slučajevima postala analogna istini; odnos između fikcionalnosti i mašte jednak je onome između istine i vjerovanja. Mašta je usmjerena prema fikcionalnom kao što vjerovanje usmjereno prema istini. $U$ ono što je istina treba vjerovati, a ono što je fikcionalno treba zamišljati. $\ll^{21}$

Prema tome, bez obzira koliko bilo transparentno, realistično slikarstvo pripada kategorijama imaginarnog svijeta jer je unutar njega (upravo kao slikarska reprezentacija) i nastalo. Za naš argument, doduše, važnije je ono što Kendall Walton kaže u svom kasnijem tekstu, a to je da transparentnost fotografije definitivno ne pripada onoj kategoriji vizualnog iskustva kojoj pripadaju 
neke druge vrste mimetičke reprezentacije (poput slikarstva, skulpture, itd.). Naime, Walton smatra da stupanj realističnosti nekog prikaza ne ovisi o stupnju njegove mimetičnosti, nego o tome pripada li dotični prikaz kategoriji mašte ili kategoriji istine. Kod fotografije ne mogu biti primijenjena pravila igre make-believe jednostavno zato što je riječ o drugačijim pravilima percepcije: kod fotografije ne zamišljamo da nešto vidimo, nego vjerujemo da to vidimo. ${ }^{22}$ Premda je temeljna razlika između fotografije i slikarstva to što ona uvijek prikazuje nešto što doista postoji, dok slikarstvo ne mora nužno prikazivati stvarno postojeće predmete, mnogo značajnije je to što nam je fotografija donijela potpuno novi način gledanja mimetičnih prizora: naime, takvo gledanje koje više nema nikakve veze s post-renesansnim nastojanjem za realizmom u slikarstvu ili s uobičajenim teorijama realistične umjetnosti. Za Waltona je fotografija nešto poput »supertransparentnog« medija kroz koji doista vidimo ono što fotografija prikazuje. ${ }^{23}$

Ovaj uvid je za nas važan zato što Walton u njemu problematiku transparentnosti definitivno izdvaja iz područja teorije reprezentacije i pokazuje da je riječ o dvjema potpuno različitim kategorijama vizualnog iskustva koje kategorije ovise o dvije neusporedive teorijske premise: o fenomenologiji gledanja u slučaju transparencije i o semiotici slikovnog znaka u slučaju reprezentacije. Prema tome, iz Waltonovih uvida mogli bismo izvesti zaključak da maksimalna transparentnost slike može voditi prema imerzivnom vizualnom iskustvu, pod uvjetom da tehnika vizualizacije kojom se to postiže omogućuje slikovnu istinu u koju se može vjerovati (a ne da ju treba zamišljati, kao kod slikarstva). Transparentnost fotografije tek je jedan, doduše vrlo mali ali povijesno verificirani, korak prema medijskim strategijama transparencije koje danas primjećujemo u sve većim dimenzijama televizijskih ekrana, predimenzioniranim IMAX kinematografskim platnima, 3D tehnologijama, naočalama za virtualnu stvarnost i sl. Oliver Grau je u knjizi Virtual Art. From Illusion to Immersion pokazao da je svojevrsna »poetika transparencije« oduvijek bila prisutna u slikovnim reprezentacijama zapadne umjetnosti i ovisila je kako o aktualnim skopičkim režimima u pojedinim povijesnim razdobljima tako i o raspoloživim tehnologijama vizualizacije.

Možda bismo zato modernistički prevrat u drugoj polovici 19. stoljeća i apstraktnu umjetnost što je iz njega proizašla danas trebali više promatrati kao sukob s poetikama transparencije negoli kao sukob s tradicijom realizma. Takav zaključak izvodim iz uvjerenja da je slikovna imerzija, tj. stapanje slikovnog iskustva sa stvarnošću dio povijesnog procesa teleologije reprezentacije - čovjekova poriva da proizvodi slike koje će opisivati, nadomjestiti ili popraviti stvarnost. Dakle, drugi paradoks načela transparentnosti sastoji se u tome što su se u ontološkom smislu najviše približili »stvarnoj slici« oni prikazi koji su se uspjeli najviše udaljiti od »slike stvarnosti« - naravno, riječ je o radikalno netransparentnim slikama apstraktne umjetnosti.

18

Kendall Walton, »Transparent Pictures. On the Nature of Photographic Realism«, u: Kendall Walton, Marvelous Images. On Values and the Arts, Oxford University Press, 2008.

19

K. Walton, »Transparent Pictures. On the Nature of Photographic Realism«, str. 83.

20

Kendall Walton, Mimesis as Make-Believe. On the Foundations of the Representational
Arts, Harvard University Press, Cambridge 1993., str. 38

21

K. Walton, Mimesis as Make-Believe, str. 41

22

K. Walton, »Transparent Pictures«, str. 8587.

23

Ibid 
Podjela slika prema transparentnosti ima za cilj uvesti multidisciplinarni kriterij koji bi slikama pristupao iz pozicije njihova odnosa prema realitetu tehnosfere, a ne, kao što je to slučaj u tradicionalnim vizualnim disciplinama, iz pozicije odnosa prema pojmu ili idealu stvarnosti. Ovdje je riječ o ključnom obratu koji prije svega uzima u obzir da više ne postoji samo jedna stvarnost, a koju bi se nekom iznimnom slikarskom vještinom ili visokopreciznim tehnologijama reprodukcije moglo savršeno oponašati. Radi se o tome da je klasični renesansni ideal slikovne transparencije ušao ne samo u područje tehnološke reproduktibilnosti, kao što je već Walter Benjamin ustanovio u svom čuvenom eseju, nego je danas prije svega riječ o tehnološkoj generativnosti digitalnog koda, tj. o postajanju slikom kao nematerijalnim vizualnim fenomenom. Apstraktna umjetnost, kao što smo vidjeli kod Martina Seela, čuva materijalno iskustvo i neprozirnost slike kao ikoničke razlike, dok nas digitalne tehnologije uranjaju u područja simulacije koja nedvojbeno pružaju neku vrstu sinestezijskog totalnog iskustva vizualnosti - ali vizualnosti koja više nije slika.

\section{Medijalnost: materijalne (picture), imaginarne (image) i digitalne (virtuality) slike}

Kada govorimo o podjeli slika prema medijskoj osnovi odmah na početku treba napomenuti da ovdje nije riječ o podjeli prema različitim tradicionalnim vrstama medijskih »nosača«, poput grafičkih otisaka, fotografskih negativa i pozitiva, novinskog tiska, ekranskih prikaza i sl., nego je riječ o tangibilnosti kao kategorijama materijalnog i nematerijalnog pojavljivanja. Prvenstveno se ovdje referiram na klasičnu Mitchellovu podjelu: na pojam picture koji objedinjuje materijalne, čvrste ili trodimenzionalne predmete kod kojih jedna od površina služi kao nositelj vizualnih informacija; zatim na pojam image koji se odnosi na nematerijalne, čisto optičke vizualne senzacije prisutne u čovjekovu umu u neurokognitivnom obliku mentalne svijesti ili nematerijalnog slikovnog doživljaja; naposljetku, mislim da Mitchellovoj podjeli treba dodati treću medijalnu osnovu koja nije generirana ni indeksacijom (ostavljanjem traga) na nekom materijalnom nosaču, a nije ni čista mentalna slika, nego ovisi prije svega o elektronskim impulsima - riječ je o onoj vrsti slike koju Friedrich Kittler zove »izračunatom slikom «, dakle o digitalnom zapisu. ${ }^{24}$

Zašto smatram da teorija slikovnog pojavljivanja mora uzeti u obzir ovu radikalno pojednostavljenu podjelu medijalnih osnova slike? Drugačije rečeno, zašto smatram da je za suvremenu interdisciplinarnu teoriju slike važnije, primjerice, uočiti razliku u medijalnoj osnovi između mehaničke i digitalne slike ili mentalne i hologramske slike na jednoj strani negoli između grafičkog otiska i ulja na platnu na drugoj? Prvi dio odgovora na ovo pitanje je jednostavan: ponajprije zato što se teorija slikovnog pojavljivanja, kako je ovdje zamišljena, bavi ontološkim problemima slika, a ne njihovom umjetničkom vrijednošću ili društvenom funkcijom. Medijalnost slike u vezi je s njenim porijeklom kao vizualnim fenomenom, a ne s označiteljskim, vrijednosnim ili identitetskim teorijama, poput semiotike, povijesti umjetnosti ili rodnih studija. Drugi dio odgovora manje je povezan sa spomenutim akademsko-disciplinarnim kriterijima i zato je teorijski specifičniji. Naime, u teoriji slikovnog pojavljivanja, pored drugih kriterija koje navodim (temporalnost, transparentnost i referencijalnost), potrebno je preciznije definirati na koji način slike dolaze u svijet, kako nam se one ukazuju i što ih omogućuje. Kako smo ranije vidjeli, Martin Seel je potpuno svjestan da je probleme značenja, vrijednosti 
i identiteta, koliko god oni sami po sebi bili važnima u zapadnoj povijesti umjetnosti, potrebno sagledati ne kao vrijednosti u odnosu na neki estetski ide$a l$, a što je slučaj kod tradicionalnih disciplina, nego da je estetsku vrijednost uvijek potrebno iznova konstituirati u prostoru što se otvara između pojavnosti i pojavljivanja. Podsjetimo se: kod Seela je pojavnost (appearance) univerzalna faktualnost nekog predmeta, dok je pojavljivanje (appearing) estetska operacija koja ovisi o specifičnom, trenutnom odnosu jednog i drugog.

Sâmo slikovno pojavljivanje oslobođeno je tog odnosa jednostavno zato jer nas ovdje, kako smo rekli, ne zanima estetsko-vrijednosna komponenta slike nego ono kako je vidimo, tj. kako nam se ona ukazuje. Ovaj problem utoliko ćemo uspješnije analizirati ukoliko upotrijebimo jednu ekskluzivniju teoriju, onu koja namjerno izostavlja estetsku komponentu slika: pritom mislim na »logiku ikoničkih struktura« Dietera Merscha. Na vrlo jasnom tragu koncepta »ikoničke razlike«, Mersch ulazi mnogo dublje od samog Gottfrieda Boehma u problematiku slikovnog iskustva te stvara od pojma slikovne diferencije znatno korisniji teorijski alat. Naime, Mersch predstavlja ikoničku razliku kao svojevrsnu »medijalnu filozofiju slike« i kaže da se medijalnost slike ne može izvesti ni iz njezinih struktura reprezentacije, ni iz simboličkog ni iz hermeneutičkog čitanja. Svaki od ovih dominantnih modela zamagljuje navlastitu slikovnu ontologiju. Potrebno je, prije svega, osmisliti i osvijestiti modele odvajanja slikovnog od ne-slikovnog, a ne jedno značenje od drugog značenja. Većina slika će ovdje stvoriti poseban problem jer će nas uvlačiti u sebe onime što prikazuju i na taj način odvraćati našu pozornost od svoje čiste medijalne osnove. Mersch smatra da je rješenje ovog problema ne u slici, nego u pogledu: samo navlastita logika pogleda može načiniti razliku između slike kao slike i slike kao stvari: »između slikovnosti i činjenja vidljivim zjapi razlika koja kao razlika ostaje nevidljiva«. Drugim riječima, slika se može konstituirati samo u svojevrsnom »rezu« ili »granici«; tu granicu, doduše, ne čini vidljivom ona sama nego tek pogled promatrača jer sama slikovna diferencija ne može na slici ili unutar slike postati vidljivom. ${ }^{25}$ Ako ikonička razlika, kao temeljno fenomenološko svojstvo slike, nije vidljiva tada to znači da ni slika nije vidljiva »po sebi« nego tek kao višestruk odnos mogućnostî pogleda, temporalnosti, transparentnosti, medijalnosti i referencijalnosti slikovnih površina.

Za teoriju slikovnog pojavljivanja, a pogotovo za njenu kategoriju medijalnosti, ovo je posebno značajno i zato ćemo se tome još malo posvetiti. Mersch ispravno tvrdi da se posebna medijalnost slike ne smije reducirati na gramatički ili retorički modus i zato semiotika, hermeneutika i ikonologija disciplinarno - tj. esencijalno - promašuju ono što bi trebalo apostrofirati kao medijalno u slici. Jedan od najočitijih primjera za to je, prema Merschu, figura ekfraze koja samo naglašava inkomenzurabilnost slike i teksta, te na taj način ili unaprijed potpisuje neuspjeh u jezičnom prikazivanju vizualnog ili kroz diskurzivnu analizu slike pretvara vizualnu medijalnost $\mathrm{u}$ nesumjerljivo iskustvo teksta. ${ }^{26}$ Međutim, nakon što odbacimo ekfrazu, hermeneutiku i tradicionalnu ikonologiju, još uvijek nismo odgovorili na pitanje što točno definira medijalnost slike? Po mom mišljenju na to pitanje je moguće odgovoriti samo ako medijalnost razumijemo kao tek jednu od četiri kategorije koje u specifičnom

24

O pojmu izračunate slike vidi u tekstu Friedricha Kittlera »Pismo i broj. Povijest izračunate slike«, Europski glasnik 10 (2005), str. 471-484.
25

D. Mersch, »Pogled i izmicanje: uz logiku ikoničkih struktura«, str. 142.

26

Ibid., str. 143. 
međuodnosu stvaraju cjelokupnu ontologiju slike. Kako ispravno primjećuje Mersch, o medijalnosti ne možemo raspravljati u kontekstu značenja i upravo zato bi svaka teorija slike svojim klasifikacijskim sustavom na to trebala upozoriti. U prilog ovome govori i ranije spomenuta tvrdnja Martina Seela da su apstraktne slike paradigmatske slike zato što ništa ne predstavljaju. Međutim, kada je ova - inače potpuno prihvatljiva - tvrdnja izrečena na ovaj način, proizlazi da je jedno uvjet za drugo, tj. da je neka slika paradigmatska upravo zato što je apstraktna. Ja bih na ovome mjestu predložio drugačiju kauzalnost: apstraktna slika je paradigmatska slika zato što je kod apstraktne slike stvoren najveći rez između njene medijalne osnove na jednoj strani i referencijalnosti na drugoj. Ili, kako bi to rekao Dieter Mersch, zato što je u slučaju takve vrste slika najvidljivija »serija rascjepa« između slike i pogleda: drugim riječima, kod percepcije apstraktne slike dolazi do cijelog niza

»... diferencija, aporija i hijazama koji definiraju različite nizove 'perforacija' - a zadatak filozofije slikovnog, koja misli iz pogleda, sastoji se u tome da se medijalnost slike i njezin specifičan užitak za oko rekonstruiraju iz te serije rascjepa. $\ll^{27}$

Poseban zadatak teorije slikovnog pojavljivanja je da na zadovoljavajući način razdvoji kategorije pojavljivanja jer, kako smo vidjeli, nije dovoljno samo razdvojiti medijalno i semiotičko/ikonološko, nego ih je potrebno dovesti u održiv odnos. Ono »čisto ikoničko« nikada neće postojati neovisno o drugim vrstama pojavljivanja i zato teorija slike mora prije svega uzeti u obzir modalitete razdvajanja i potencijalnog povezivanja naizgled nespojivih ontoloških kategorija. U to razdvajanje upućuje nas primarno fenomenologija i Husserlov koncept intencionalnosti, ali jednako tako i Mitchellova podjela na vidljive i nevidljive slike, a čemu svakako treba dodati i cijeli niz teoretičara tehnosfere, od Benjamina, Kittlera, Boltera i Grusina, do Manovicha, Massumija i Paića. Digitalna ili virtualna slika je treća medijalna osnova koja je u teorijskom smislu još uvelike tabula rasa slikovne teorije.

\section{Referencijalnost: ne-referencijalne/auto-referencijalne, referencijalne, inter-referencijalne, multi-referencijalne i meta-referencijalne slike}

Četvrti temeljni pojam slikovnog pojavljivanja je referencijalnost. Ovaj pojam srodan je terminološkom sklopu koji su koristile (i još uvijek ga koriste) tradicionalne vizualno-povijesne i vizualno-teorijske discipline, poput povijesti umjetnosti, ikonografije, hermeneutike i semiotike. Pored toga, referencijalnost još uvijek predstavlja čovjekov najizravniji način dodira sa slikama, ili barem način kojega je u svakodnevnoj komunikaciji svatko od nas najviše svjestan. Dok su temporalnost, transparentnost i medijalnost prvenstveno pojmovi iskoristivi za ciljeve refleksivnog djelovanja teorije, tj. dok ulogu ovih pojmova u potpunosti možemo razumjeti tek svojevrsnim odvajanjem medija od sadržaja slike, pojam referencijalnosti u ovoj podjeli služi nam kako bismo obuhvatili i sliku kao instrumentalni medij s izraženim komunikacijskim, diskurzivnim i narativnim funkcijama. Razloge za teorijsko razmatranje (i) raznolikih funkcija slika u ovom kontekstu svakako treba odmah razjasniti. Naime, iz svih dosadašnjih argumenata trebalo je postati razvidnim da unutar teorije slikovnog pojavljivanja instrumentalnost slike nije u prvom planu jer bi nas problematika funkcije nužno ponovo vratila esencijalističkim i subjektivističkim osobinama slika (tj. »velikim humanističkim teorijama« i politikama identiteta). Međutim, instrumentalnost slika ne možemo odbaciti u ontološkoj analizi poput naše zato što je krajnji cilj ove teorije pokazati da je 
instrumentalnost slika, tj. njihov »život« kao objekata komunikacije, upravo posljedica triju modaliteta pojavljivanja koji prethode referencijalnim funkcijama slikovne komunikacije, tj. koji bitno uvjetuju na koji način će slike biti gledane i razumijevane.

Različite kategorije referencijalnosti moguće je uspostaviti samo ako imamo podjednako u vidu klasičnu Aristotelovu tradiciju oponašanja prirode kao izvora osjetilnog zadovoljstva kao i (danas već podjednako klasičnu) semiotičku tradiciju. Ova potonja obuhvaća, među ostalima, de Saussureov koncept znaka i referenta, Barthesova tumačenja denotacije, konotacije i mitologizacije, zatim semiosferu Jurija Lotmana te pojmove što su iz nje proizašli, poput Ecovog tumačenja semioze a koji se kasnije razvio u Ecovu navlastitu kritiku semiotičkog upisivanja značenja u djelo - sovrainterpretazione. Međutim, velika semiotička tradicija ne služi nam kako bi se unutar prvenstveno fenomenološke teorije slikovnog pojavljivanja uspostavila i neka kontra-metoda znaka i značenja, nego nam je potrebna jednostavno zato što je označavanje (ili njegov namjerni izostanak) svakodnevna praksa vizualnih komunikacija. Oba ova argumenta razlog su što se naša ontologija slikovnog pojavljivanja ne može baviti pitanjima što i zašto se reprezentira, nego kako se to čini i kakvi su učinci referencijalnosti za sam pojam slikovnog prikazivanja.

Semiotička konstrukcija znaka i ulančavanja značenja (a koje ulančavanje možemo nazvati i semiozom i mitologizacijom, ovisno o izvoru), pogodan je model za razumijevanje referencijalnog pojavljivanja zato što s njim dijeli istu ideju prema kojoj je jedan vizualni iskaz uvijek u odnosu prema drugom iskazu, tj. naredni iskaz stvara se kao funkcija prethodnog ili referencija na prethodni. Ako krenemo od referencijalnosti kao »nulte točke « slikovnog značenja, onda se svaka sljedeća kategorija referencijalnosti uspostavlja u odnosu na tu nultu točku, i možemo ju nazvati izvorno značenje. Svaka druga, ili izvedena, slika koja se odnosi na izvornu sliku ovu prethodnu na izvjestan način »sadrži«, tj. na nju se referira. Jedina iznimka od ovog pravila su ne-referencijalne ili auto-referencijalne slike, ali o tome će biti riječi nešto kasnije.

Ako se udaljimo od de Saussureove koncepcije označitelja, označenog i znaka, i zamislimo znak ne kao arbitrarnu, nego kao motiviranu točku referencijalnosti (kako to predlaže Barthesov pojam mitologije i Ecov pojam semioze), tada ikonički znak može biti sve ono što u dovoljnoj mjeri podsjeća ili referira na neku izvanslikovnu stvarnost: fotografije, tiskarski otisci, ekranski prikazi, jednom riječju, slike najrazličitijih žanrova i medijalnih osnova. U modalitetu slikovne referencijalnosti najmanja jedinica značenja je ona unutar koje prepoznajemo neki dovršeni odnos ili referenciju spram stvarnosti, a taj odnos u praksi najčešće uspostavljamo s pojedinačnim (umjetničkim) slikama, filmskim sekvencama ili fotografskim snapshot-om. To su, dakle, referencijalne slike, i od njih polazi lanac semioze (ili mitologizacije značenja), a koje slike zatim ulaze u složenije odnose komentirajući i pozivajući se na početnu slikovnu referenciju. Ovo ćemo najbolje razumjeti poslužimo li se primjerom konkretnih slika i postavimo li ih u odnos s drugim slikama što iz prvih mogu proizaći ili biti iz njih izvedene. Fotografija Joea Rosenthala snimljena 1945. godine na otoku Iwo Jima postala je ikonički znak pobjede američke vojske u ratu na Pacifiku. Ona je tijekom godina postala mnogo više nego što nam govori njena instrumentalna funkcija, tj. postala je mnogo više od slikovne reference na događaj koji prikazuje - postavljanje američke zastave. Međutim, njeno prvobitno ili »nulto« značenje u semiotičkom lancu mora biti svedeno 
na puku referencijalnost jer nikakvo drugo značenje ne bi moglo nastati da nije zabilježen taj prvi fotografski snapshot koji je u trenutku nastajanja fotografije značio samo ono što prikazuje.

S druge strane, reklamna fotografija nastala 1990. godine za brand H.I.S. Jeans ne prikazuje samo mladiće i djevojke koji podižu američku zastavu, nego vrlo jasno ulazi u dijalog s mitskim značenjem Rosenthalove fotografije snimljene nekoliko desetljeća ranije. Reklamna fotografija je, nedvojbeno, referencijalna ali je istodobno - i mnogo više - inter-referencijalna jer mnogo veći dio značenja ona preuzima od mitske pozicije Rosenthalove fotografije negoli od vlastite referencijalnosti koja se bazira na mimetičkom prikazu četvoro mladih što podižu američku zastavu. Dakle, njena vlastita referencijalnost služi samo kako bi se nadovezala na neko drugo, prethodno značenje. U tom trenutku, motiv podizanja američke zastave već je ušao u multi-referencijalno polje u kojemu izvorni (Rosenthalov) znak herojstva i reklamno (ironijsko) herojstvo otvaraju prostor u kojemu se svako naredno referiranje na izvornu ili ironijsku sliku isprepliću i izlaze »izvan kontrole«. Takav primjer multi-referencijalne slike je fotografija Thomasa Franklina snimljena 11. rujna 2001. na ruševinama njujorških Twinsa koja prikazuje trojicu vatrogasaca kako postavljaju američku zastavu u maniri američkih vojnika na Iwo Jimi, ali jednako tako i u maniri bezbrižne mladeži iz reklame za traperice. Na koju se od ove dvije fotografije referira Franklinov snapshot vatrogasaca? Na izvorni znak herojstva ili na ironijsku persiflažu koja želi dovesti u pitanje mit o američkoj nepobjedivosti? Premda je Franklinova izvedba vjerojatno bila potaknuta inter-referencijom na Rosenthalov ikonički rad, fotografija se u otvorenoj sferi kulture nužno referira na obje prethodne jer njeno značenje ne može izbjeći semiotičko ulančavanje u bilo kojem smjeru. Zato je riječ o multi-referencijalnoj slici. Multi-referencijalnost je mnogo složeniji oblik slikovnog međuodnosa jer ne samo da uključuje pozivanje na nepregledno mnoštvo ikonografskih izvora, nego i zato što se u tom procesu ne može isključiti djelovanje nerijetko suprotstavljenih ideoloških diskursa koji također čine dio referencijalnog obuhvata slike.

Meta-referencijalne slike su ono što W. J. T. Mitchell naziva metapictures: slike koje upućuju na same sebe, tj. na nekoliko razina vlastite ontološke pozicije: 1) razotkrivaju način na koji su one same napravljene ili pak na mehanizam proizvodnje slikovnog značenja uopće; 2) oslikavaju svojevrsnu »teoriju o slikama « ne izlazeći iz vlastitog slikovnog medija, tj. postavljaju pitanje je li moguće govoriti o slikama bez ekfraze, bez jezika kao verbalnog nadomjeska; 3) razotkrivaju bitnu slikovnu prirodu: naime, slika, da bi uopće funkcionirala kao komunikacijski medij, ne smije biti poistovjećena sa stvarnošću, ali niti sa samom sobom. ${ }^{28}$ Mitchellov pojam metaslika (ili, slikovne meta-referencijalnosti u našem slučaju), u načelu postavlja pitanje mogu li slike raspravljati same o sebi, umjesto da to za njih čine tradicionalne discipline ikonologije i semiotike. Kada su slike usmjerene prema samima sebi i kada razotkrivaju modele proizvodnje svih drugih slika, one tada postaju subverzivni mehanizmi koji mogu razotkriti institucije i diskurzivnu proizvodnju moći. Jedan od najpoznatijih primjera takve vrste slika je Las Meninas Diega Velázqueza koja složenim sustavom, inter-, multi- i meta-referencijalnosti propituje status ikoničkog općenito kao mehanizma političke proizvodnje moći.

Zanimljivo je da Mitchell kaže da su metaslike istodobno radikalno upućene na sebe same, tj. stvaraju vlastitu unutar-slikovnu teoriju slike, ali su i intertekstualne, dakle stvaraju značenje ulančavanjem s brojnim drugim slikovnim iskazima što paralelno su-postoje unutar vizualne kulture neke zajednice ili povijesnog razdoblja. Uzmemo li u obzir Mitchellovu argumentaciju i kon- 
cept referencijalnosti koji ovdje nastojim obraniti, proizlazi da se metaslike ili meta-referencijalne slike vraćaju na sam početak slikovne referencijalnosti, tj. na auto-referencijalnost ili radikalnu upućenost slike na samu sebe. Paradoksalno, slike koje su najviše upućene na same sebe, kako smo ranije vidjeli kod Martina Seela, su upravo one koje na ništa ne referiraju osim na same sebe - dakle, slike apstraktne umjetnosti. Mislim da bismo tom paradoksu mogli pristupiti na sljedeći način: naime, i ne-referencijalne, tj. autoreferencijalne slike na jednoj strani i metareferencijalne slike na drugoj samo na različite načine potvrđuju istu temeljnu slikovnu ontologiju koju Gottfried Boehm naziva ikonička razlika. I jedna i druga vrsta slika do kraja razotkrivaju vlastitu drugost u odnosu na izvanslikovnu stvarnost: prva to čini naglašavanjem razlike između slike i svijeta, dok druga to čini radikalnom dekonstrukcijom načina na koji je kulturalno proizvedena.

Svaka slika koja se pojavljuje u nekom referencijalnom modalitetu - bez obzira odnosila se ona na nešto izvan sebe (referencijalnost) ili se pak odnosi na sebe samu (ne-referencijalnost i auto-refererencijalnost) - može u načelu posjedovati samo dva ranije spomenuta temporalna modaliteta: reprezentacionalnost i simultanost. Naime, u slikovno-ontološkom smislu svejedno je gledamo li u izravnom prijenosu (kao ikoničku simultanost) sliku koja nešto prikazuje ili nas na nešto podsjeća (dakle, referencijalna je) ili gledamo ne-referencijalne, tj. apstraktne slike (primjerice, kada u izravnom prijenosu otvorenja izložbe gledamo krupni plan neke apstraktne slike). Ova potonja slika bila bi simultana i ne-referencijalna. Međutim, ne možemo nazvati slikovnim iskustvom malo vjerojatnu (ali ipak moguću situaciju) u kojoj bi se ispred dvaju kompjuterskih ekrana s uključenim web kamerama nalazile dvije ne-referencijalne slike i »gledale« jedna drugu. Ova hipotetska situacija potvrđuje da je učinak referencijalnosti neovisan o učinku temporalnosti ali samo ukoliko je zadovoljen uvjet koji Edmund Husserl naziva »slikovnom sviješću«. Drugim riječima, slika, kako bi se uopće pojavila, bez obzira na stupanj vlastite referencijalnosti, mora biti »proizvedena« pogledom. Nužnost postojanja slikovne svijesti govori nam o tome da taj temeljni fenomenologijski uvid uspostavlja granicu iza koje percepcija slike više nije moguća.

S druge strane, premda smo vidjeli da slika ne postoji bez intencionalne svijesti (promatrača) koja ju proizvodi, Jean-Paul Sartre kaže da to dvoje - percepcija i slika - nisu jedno te isto. Iz toga proizlazi da ono što čin percepcije ipak čini neodvojivim od objekta percepcije je tek proizvod svijesti koja pristaje na kognitivnu konvenciju koju Sartre naziva »iluzija imanencije «. ${ }^{29}$ Iluzija imanencije nužna je u komunikacijskom sustavu u kojemu svijest operira na drugoj razini od one fizičkih objekata, čak i kada su ti objekti na izvjestan način ugrađeni u svijest i s njome čine kontinuum. Iluzija imanencije omogućava da se kontinuum sam ne razotkrije, tj. ona omogućava da slike doživljavamo kao da jesu ono što prikazuju, premda one nisu to što prikazuju nego su jednostavno - slike. ${ }^{30}$ Modaliteti slikovnog pojavljivanja otvaraju mogućnost

28

Vidi o tome opširnije u Mitchellovom tekstu »Metaslike« objavljenom u: Krešimir Purgar (ur.), Vizualni studiji. Umjetnost $i$ mediji $u$ doba slikovnog obrata; Centar za vizualne studije, Zagreb 2009.

29

O tome vidi Jean-Paul Sartre, The Imaginary. A Phenomenological Psychology of the Imagination, Routledge, London 2004. [1940], str.
12; John Lechte, »Some Fallacies and Truths Concerning the Image in Old and New Media«, Journal of Visual Culture 10 (3/2011), str. 354-377, str. 357-358. doi: https://doi. org/10.1177/1470412911419762.; Krešimir Purgar, »Što (više) nije slika?«, str. 166-167.

30

Jean-Paul Sartre, The Imaginary, str. 6. 
jedne »tranzicijske« teorije slike za doba koje više nije (samo) analogno i još uvijek nije (samo) digitalno - teorije koja uzima u obzir široki prostor između objekata i percepcije, tj. između eikona i čiste osjetilnosti.

\title{
Krešimir Purgar
}

\section{Modalities of Pictorial Appearing: Basic Concepts}

\begin{abstract}
The proliferation of digital technology requires from us to think about images in a new way. We should no longer refer to them only as Greek eikon, that is, reflection or representation, but as experiences, events and special kind of appearing. In contemporary digital culture pictorial appearing is the symptom of the most recent turn towards images, the one that is happening after the "original" pictorial turn that was described by W. J. T. Mitchell and Gottfried Boehm almost three decades ago as the epoch-making new kind of relationship between images and language. Today we witness a different kind of urgency: the one that will exemplify the relationship between analogue images and digital images, representations and post-representations, reality and virtuality, semiotics and phenomenology. In this article I will propose a "transitional" theory of the image that takes into account the wide gap between objects and perceptions, that is, between eikon and pure sensuousness. To this end, I will introduce the four basic modalities of pictorial appearing: temporality, transparency, mediality and referentiality.
\end{abstract}

\section{Key words}

image ontology, pictorial appearing, Martin Seel, Dieter Mersch, temporality, transparency, mediality, referentiality 